\title{
ACQUISITIONS AND FOREIGN COMPETITION
}

by

Shweta Srinivasan

A Dissertation Submitted to the Faculty of the

\section{DEPARTMENT OF FINANCE}

In Partial Fulfillment of the Requirements

For the Degree of

DOCTOR OF PHILOSOPHY

In the Graduate College

THE UNIVERSITY OF ARIZONA 


\section{THE UNIVERSITY OF ARIZONA}

\section{GRADUATE COLLEGE}

As members of the Dissertation Committee, we certify that we have read the dissertation prepared by Shweta Srinivasan, titled Acquisitions and Foreign Competition and recommend that it be accepted as fulfilling the dissertation requirement for the Degree of Doctor of Philosophy.

Date: March 24, 2015

Sandy Klasa

Date: March 24, 2015

Lubomir Litov

Date: March 24, 2015

Ryan Williams

Date: March 24, 2015

Satheesh Aradhyula

Final approval and acceptance of this dissertation is contingent upon the candidate's submission of the final copies of the dissertation to the Graduate College.

I hereby certify that I have read this dissertation prepared under my direction and recommend that it be accepted as fulfilling the dissertation requirement.

Date: March 24, 2015

Dissertation Director: Sandy Klasa 


\section{STATEMENT BY AUTHOR}

This dissertation has been submitted in partial fulfillment of the requirements for an advanced degree at the University of Arizona and is deposited in the University Library to be made available to borrowers under rules of the Library.

Brief quotations from this dissertation are allowable without special permission, provided that an accurate acknowledgement of the source is made. Requests for permission for extended quotation from or reproduction of this manuscript in whole or in part may be granted by the head of the major department or the Dean of the Graduate College when in his or her judgment the proposed use of the material is in the interests of scholarship. In all other instances, however, permission must be obtained from the author.

SIGNED: SHWETA SRINIVASAN 


\section{ACKNOWLEDGEMENTS}

I am very grateful to my dissertation committee members Lubomir Litov, Ryan Williams and Satheesh Aradhyula for their support and helpful comments. I am especially grateful to Sandy Klasa, my dissertation chair, for his guidance and many valuable comments and suggestions. I also thank Matthew Serfling, Douglas Fairhurst, and faculty and Ph.D. students at the University of Arizona for their helpful comments. Finally, I am grateful to my family, especially my husband Srini and my daughter Meera, for their love, support and constant encouragement that has made my work possible. 


\section{Contents}

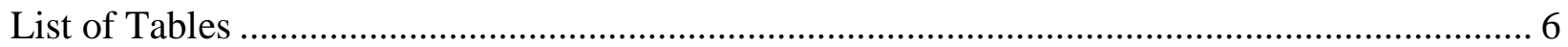

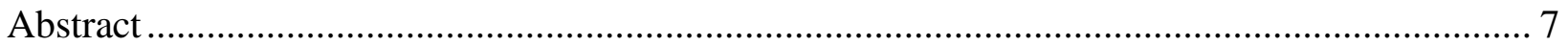

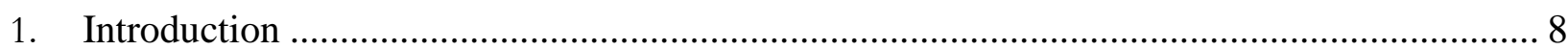

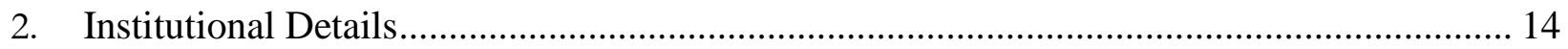

3. Related Literature and Hypothesis Development ................................................................ 16

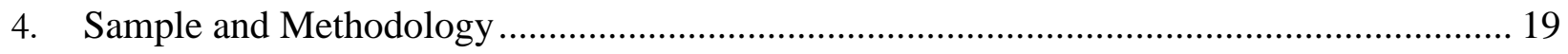

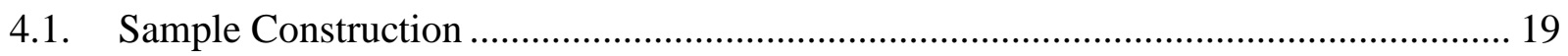

4.2. Measurement of Foreign Competition …………........................................................ 20

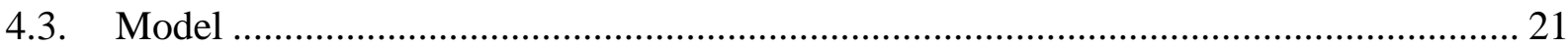

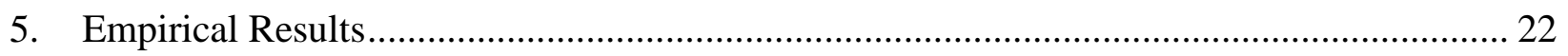

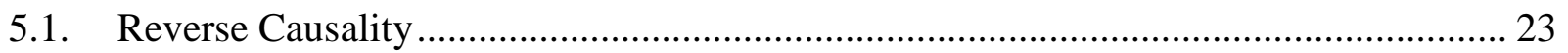

5.2. Likelihood of Acquisition and Post-Acquisition Efficiency Gains................................. 24

5.3. Financial Constraints and Likelihood of Acquisition ................................................... 26

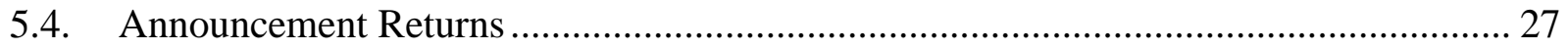

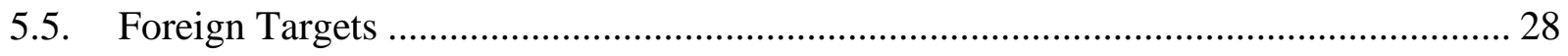

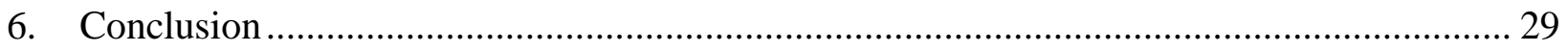

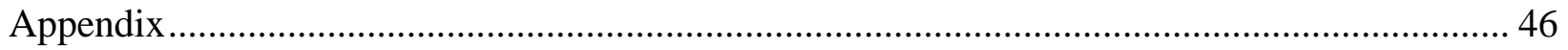


References.

\section{List of Tables}

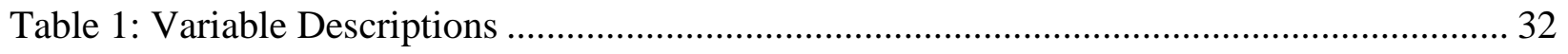

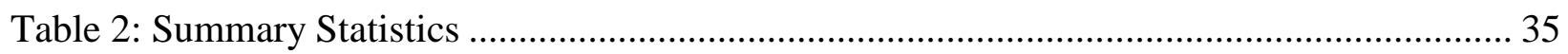

Table 3: Average Change in Import Tariffs by Industry ........................................................... 36

Table 4: Foreign Competition and Likelihood of Acquisitions .................................................... 37

Table 5: Timing of the Relation between Likelihood of Acquisitions and Tariff Decreases ........ 38

Table 6: Likelihood of Acquisitions and Post-Acquisition Efficiency Gains................................. 39

Table 7: Likelihood of Acquisitions by Financially Constrained Firms ........................................ 41

Table 8: Announcement Returns to Acquisitions around Tariff Decreases ................................. 43

Table 9: Likelihood of Acquiring Foreign Targets ..................................................................... 45

Table A1: Logit Regression of Acquisition Likelihood on Tariff Decreases ................................ 46 


\begin{abstract}
I provide evidence on the impact of foreign competition on firms' propensities to engage in mergers and acquisitions. Using import tariff reductions as an exogenous shock that increases foreign industry competition, I find that affected firms are more likely to make acquisitions following a tariff reduction. Cross-sectional tests show that this association is more pronounced for single segment firms, firms that innovate less, or that are more capital intensive, which suggests this association is stronger for firms which stand to gain more from an acquisition. Moreover, the positive relationship between acquisition likelihood and tariff cuts is less pronounced for financially constrained firms and during times of low capital liquidity, which implies that it is easier for firms with greater access to external capital to respond to increases in foreign competition by making acquisitions. Finally, I find that acquisitions made subsequent to tariff decreases are associated with positive wealth gains for bidder shareholders, indicating that these acquisitions are viewed favorably by market participants.
\end{abstract}




\section{Introduction}

Prior work identifies several motives for corporate acquisitions. For example, Harford (1999) finds that cash rich firms suffering from agency problems are more likely to make acquisitions while Malmendier and Tate (2005) argue that mergers are a manifestation of CEO overconfidence. Shleifer and Vishny (2003) and Rhodes-Kropf and Viswanathan (2004) develop models that predict that acquisition activity is driven by managers taking advantage of market overvaluations of their firms. Extant literature also cites synergies as a motivation for acquisitions (Rhodes-Kropf and Robinson (2008), Hoberg and Phillips (2010)). Mitchell and Mulherin (1996) argue that merger waves are a result of firms responding to industry-level shocks including deregulation (Becher (2000), Becher and Campbell (2005)), foreign competition, and financing innovations. Harford (2005) further examines this question and finds that economic, regulatory, and technological shocks in an industry initiate merger waves, but only if firms have sufficient liquidity to undertake restructuring activities.

In this paper, I examine how acquisition activity within an industry changes in response to changes in foreign competition. While there is evidence in the industrial trade literature that foreign competition reduces price-cost margins (Katics and Petersen (1994), and Harrison (1994)), increases productivity (Haddad and Harrison (1993), Harrison (1194), Pavcnik (2002), and Fernandes (2007)) and results in asset reallocation (Bertrand, Schoar and Thesmar (2007)), little is known about the acquisition activity of firms in response to increased foreign competition. Increased foreign competition forces domestic firms to improve efficiency (Walter and Gray (1983) and Claessens, Demirgüç-Kunt and Huizinga (2001)). Given that firms often use acquisitions to respond to industry level shocks (Mitchell and Mulherin (1996), Mulherin and 
Boone (2000), and Andrade and Stafford (2004)), I argue that domestic firms will be likely to make acquisitions to respond to increased competition from foreign firms.

Following Fresard (2010), Xu (2012), and Fresard and Valta (2013), I measure increases in foreign competition using data on decreases in import tariffs for the period 1997 to $2010^{1}$. An advantage of using import tariffs to measure changes in industry competition structure is that a reduction in tariffs is an exogenous shock with respect to firms' decisions to merge. Using changes in import tariffs affords a quasi-natural experiment that establishes a causal relationship between foreign competition and acquisition activity within an industry. I find that U.S. firms' propensity to acquire increases by $31 \%$ to $48 \%$ subsequent to a decrease in import tariffs. This result is consistent with the hypothesis that firms increase their acquisition activity in response to greater foreign competition.

To test whether import duties are indeed an exogenous industry shock, I examine the timing of the relation between likelihood of making acquisitions and increased foreign competition. If reverse causality was an issue, the likelihood of making an acquisition should increase in the years prior to tariff reduction. I find no significant increase in firms' propensities to make an acquisition in the year preceding a tariff cut. I do, however, document a positive relation between a tariff decrease and the likelihood of acquisitions by firms in the affected industries in the years of and following the tariff cut. These results suggest that the above findings are unlikely to be driven by reverse causality.

\footnotetext{
${ }^{1}$ Prior research uses import penetration ratio as a measure foreign competition, which suffers from concerns of potential reverse causality. Import penetration ratio is defined as the ratio of imports to the sum of imports and domestic product.
} 
I further investigate the cross-sectional variation in acquisition likelihood with respect to several firm characteristics. First, in response to increased foreign competition, firms may choose to either innovate internally or acquire other firms that innovate (e.g., Blonigen and Taylor (2000), and Phillips and Zdhanov (2013)). If firms are indeed optimally acquiring targets to respond to increased foreign competition, it follows that firms with lower internal innovation will be more likely to make acquisitions when import tariffs decrease. Consistent with this argument, I find that the positive association between tariff decreases and the likelihood of acquisitions is more pronounced for firms with lower R\&D expenses and for firms in low innovation industries. In other words, given that innovation provides firms with competitive advantage over other firms, companies that are more likely to benefit from acquiring innovation externally are more likely to engage in merger and acquisition activity following an increase in firm competition.

Extant literature also cites reduced operating costs and/or capital investments as a potential source of post-merger gains (Bradley, Desai and Kim (1988), Devos, Kadapakkam and Krishnamurthy (2009)). These gains are more valuable for firms with higher capital investments, since these firms will be able to eliminate duplication of capital investments following acquisitions. If firms respond to increased foreign competition by restructuring to improve production efficiencies, then firms with a higher proportion of capital investments are more likely to make acquisitions in response to a tariff decrease. Using the labor-to-capital ratio as an inverse measure of capital intensity, I find that the positive association between acquisition likelihood and tariff decrease is more pronounced for firms with a higher capital-to-labor ratio.

Multi-segment firms may be able to offset any reduction in cash flows resulting from increased foreign competition with cash flows from other segments that might be more 
profitable. Since single segment firms are undiversified in their exposure to changes in competition in that industry, such firms have greater incentives to respond to increased foreign competition. Consistent with this prediction, I find that single segment firms are more likely to make acquisitions in response to tariff reductions compared to multi-segment firms.

Further, prior work argues that industry shocks create incentives for transfer of assets to more productive uses. In times of industry expansion, more productive firms tend to acquire assets from less productive firms since a more productive firm will gain more value from the assets it controls (e.g., Maksimovic and Phillips (2001)). In other words, firms with higher operating efficiency will be more likely to make acquisitions in response to increased foreign competition. Consistent with this conjecture, I find that within industries that face a tariff cut, firms with higher gross margins are more likely to make acquisitions. Overall, these findings indicate that firms that stand to gain more by acquiring are the ones more likely to make acquisitions in response to increased foreign competition.

However, firms need to have the wherewithal to be able to respond to increases in competition. I next examine how financial constraints affect the association between increases in foreign competition and firms' propensities to engage in mergers and acquisitions. Firms with lower financial constraints will have better access to capital to respond to increased foreign competition by acquiring target firms. I show that firms with better z-scores are more likely to respond to tariff cuts through the acquisition channel, implying that financially constrained firms are less able to respond to increased foreign competition by making acquisitions. These results are robust to using alternate measures of financial constraints. In particular, in industries that face a tariff cut, firms with bond ratings and investment grade bond ratings are more likely to make 
acquisitions. Following Harford (2005), I use the Commercial and Industrial Loan (C\&I) spread as an indicator of market liquidity and find that the increase in probability of acquisition is more pronounced when the C\&I spread is lower. Overall, these results suggest that availability of sufficient capital is an important determinant of the acquisition activity in the face of increased foreign competition.

To further investigate the positive association between acquisition likelihood and foreign competition, I examine the impact of firms' response to foreign competition on shareholders' wealth $^{2}$. If increased takeover activity by firms is an optimal response to increased foreign competition, then the announcement of such acquisitions should be viewed favorably by market participants. Consistent with this proposition, I find that announcement returns are $1.2 \%$ to $2.9 \%$ higher for firms that make acquisitions in response to a tariff decrease.

The evidence thus far indicates that firms merge to gain operational efficiencies to enable them to respond to increase in foreign competition. Another way of achieving this could be to diversify into foreign markets that provide access to labor and materials at lower costs (Dunning (1998), Bertrand, Muchhielli and Zitouna (2007)). To the extent that firms respond to decreases in tariffs by trying to take advantage of cost efficiencies, one should observe an increase in the probability of domestic firms acquiring foreign targets. Testing this hypothesis on a sample of foreign target acquisitions, I find that domestic firms are more likely to acquire foreign targets following tariff reductions. Further, I posit that these results should be driven by larger firms that have the requisite resources to enter foreign markets. When faced with increased competitive pressures, one would expect the larger firms to be more likely to acquire foreign targets.

\footnotetext{
${ }^{2}$ See Jensen and Ruback (1983), Jarrell, Brickley and Netter (1988) and Andrade, Mitchell and Stafford (2001) for a review of these studies.
} 
Consistent with this prediction, I find that larger domestic firms are more likely to acquire foreign targets in response to tariff decreases.

The contribution of this paper is threefold. First, I contribute to increasing our current understanding of the motives for firms to make acquisitions. Empirical evidence in Mitchell and Mulherin (1996) as well as Harford (2005) suggests that merger waves are driven by industry shocks like deregulation and financing innovations. Whereas research in this area has extensively examined the association between takeover activity and deregulation as an industry shock, this paper fills the gap in literature by showing that firms make acquisitions in response to increased foreign competition. This study also provides empirical evidence that firms that acquire in response to increased foreign competition do so to achieve synergies and efficiency gains. This finding is consistent with Rhodes-Kropf and Robinson (2008) and Hoberg and Phillips (2010) who find that firms merge to exploit synergies.

Second, I contribute to the growing literature on how competition affects corporate decisions. Prior studies examine the relation between competition and leverage (Chevalier (1995), Phillips (1995), Xu (2012)), cash holdings (Haushalter, Klasa and Maxwell (2007), Fresard (2010), investment policies (Fresard and Valta (2013)) as well as cost of debt (Valta (2012)). My study provides insights on how an increase in foreign competition affects firms' propensities to engage in acquisitions.

Finally, using import tariffs as a measure of foreign competition affords a quasi-natural experiment setting that allows one to make causal inferences about the results presented herein. Recent studies use reduction in import duties as an exogenous shock to industry competitive structure to address questions pertaining to various corporate policies like capital structure and 
cash holdings. However, to my knowledge, this paper is the first to closely examine the impact of increased foreign competition on the acquisition activity within an industry.

The remainder of the paper is organized as follows. Section 2 provides an overview of the institutional setting in U.S. with regard to international trade. Section 3 discusses the existing literature and hypothesis development. Section 4 presents the data and methodology, while Section 5 discusses the empirical results. Section 6 concludes.

\section{Institutional Details}

Tariffs impose additional costs on foreign manufacturers, thereby increasing the price of imported goods relative to domestically produced ones. Economists favoring free trade have long since argued that the costs of tariffs outweigh the benefits. Governments levy import tariffs to protect nascent as well as mature domestic industries from foreign competition by increasing the export costs for the foreign rivals ${ }^{3}$. Anderson and van Wincoop (2004) find that import tariffs are a significant proportion of overall trade costs. Import tariffs can also help discourage foreign producers from "dumping" their goods in the domestic markets. Additionally, tariffs also generate revenue for the government imposing them. However, tariffs imposed to protect domestic producers cause increased prices, which in turn result in reduced demand and therefore reduced production. In the long run, this can lead to job losses and reduced productivity in the economy. As a result, over the years economies worldwide have been moving towards gradually lowering barriers to international trade.

\footnotetext{
${ }^{3}$ Governments can also impose non-tariff barriers like import quotas to discourage foreign exporters, or offer subsidies to domestic producers. However, the 'tariffication' process as part of the 1995 Uruguay round converted all non-tariff trade barriers to tariffs. Absolute import quotas were either converted to import tariffs or tariff based quotas.
} 
Barriers in international trade have largely been governed by agreements under General Agreements in Tariffs and Trade (GATT)/World Trade Organization (WTO). The GATT was a multilateral agreement, first signed in 1947, established with the purpose of regulating international trade and reducing trade barriers. The Uruguay round of GATT in 1995 is the most notable for eliminating absolute quotas and import bans in the agricultural sector. The Uruguay round is also notable for the establishment of WTO. The WTO is a set of agreements that outlines principles of international trade, procedures for settlement of disputes, and requires member countries to formulate trade policies in accordance with the agreement ${ }^{4}$. The principles of GATT still form the basis of the WTO agreements.

The United States International Trade Commission (USITC) is responsible for maintaining U.S. commitments under the GATT/WTO. U.S. has been a member of the GATT and later the WTO since 1948. Thus, any tariff reductions made by the U.S. Government in my sample would be in accordance with the GATT/WTO agreements. This implies that the tariff cuts in my sample are truly an exogenous industry-level shock to domestic firms, albeit non-random ${ }^{5}$. This affords a quasi-natural experiment setting to study the causal relationship between tariff reductions and firms' propensity to make acquisitions.

Another important aspect of GATT/WTO agreements are "bound" tariffs - tariff rates that are committed under the agreements and are difficult to increase ${ }^{6}$. An important outcome of the

\footnotetext{
${ }_{5}^{4}$ For details on WTO agreements, see http://www.wto.org/english/thewto_e/whatis_e/tif_e/utw_chap2_e.pdf

${ }^{5}$ The WTO agreements lay out a roadmap for phased tariff reductions by member countries. The approximate time and magnitude of tariff reductions can be anticipated, making these non-random events.

${ }^{6}$ In other words, tariff bounds are ceilings above which members cannot apply tariffs. However, such bounds can be changed after negotiations with the trading partners and countries can still increase tariffs where it is deemed necessary and reasonable, although the negotiations could mean compensating the trading partners for loss of trade. For example, in 2009 U.S. increased tariffs on passenger and light truck tires imported from China. See http://online.wsj.com/news/articles/SB125271824237605479 for full article.
} 
Uruguay Round was the significant increase in the number of imports that were bound. The WTO website states that developed countries increased the number of imports with bound tariffs from $78 \%$ to $99 \%$, while developing nations increased their imports with bound tariffs from $21 \%$ to $73 \%$. Thus, after 1995 , it would have been very difficult for member nations to increase tariffs on most goods. Since U.S. has been a member throughout the sample period for this study, it is difficult to observe many instances of tariff increases ${ }^{7}$.

\section{Related Literature and Hypothesis Development}

The literature offers several reasons for why firms merge. Harford (1999) finds evidence that cash rich firms suffering from agency problems are more likely to make value decreasing acquisitions. Malmendier and Tate (2005) argue that overconfident CEOs tend to undertake value destroying mergers as they overestimate their ability to generate returns. They also find stronger negative reactions to takeover bids. Masulis, Wang and Xie (2007) find that firms with more antitakeover provisions experience significantly lower abnormal returns during the announcement period, which is consistent with the argument that managers less subject to the disciplinary actions of the market for corporate control tend to make value decreasing acquisitions. Shleifer and Vishny (2003) and Rhodes-Kropf and Viswanathan (2004) favor the managerial timing view in that they argue that merger waves occur because managers take advantage of overvalued markets.

On the other hand, Jensen and Ruback (1983) review the evidence on the market for corporate control and find that in general, corporate acquisitions are value increasing activities where the target firm shareholders gain and the bidder firm shareholders do not lose. Mitchell

\footnotetext{
${ }^{7}$ I only observe tariff increases of $0.5 \%$ or more in $4.5 \%$ of the observations, while there are $20 \%$ observations with tariff decreases of $0.5 \%$ or more.
} 
and Lehn (1990) find evidence in favor of the disciplinary action of the market for corporate control. These authors find that firms that make bad acquisitions are more likely to be subsequently taken over. Mitchell and Mulherin (1996) argue that merger waves are a result of firms responding to industry level shocks. Harford (2005) further examines this question and finds that economic, regulatory as well as technological shocks in an industry initiate merger waves, but only if firms have sufficient liquidity to undertake restructuring activities.

Prior work also documents synergistic gains as a motive for mergers (Bradley, Desai and Kim (1983, 1988), Hoberg and Phillips (2010)). Another vastly documented reason for mergers between two firms is to obtain market power. For example, Kim and Singal (1993) study airline mergers and find that efficiency gains on airfares are more than offset by the price increases due to increased market power. On the other hand, Eckbo $(1983,1985)$ does not find any evidence that firms undertake mergers to gain market power.

Yet another strand of literature examines the association between industry competition and corporate policies. For example, Xu (2012) finds a negative relationship between import competition and leverage ratios. Chevalier (1995), Phillips (1995), Zingales (1997) argue that high leverage impedes a firm's ability to compete in product markets. Grullon and Michaely (2006) show that product market competition incentivizes managers to be more efficient and have a positive effect on corporate payout policies while Hoberg, Phillips and Prabhala (2013) find that firms facing competitive threats adopt more conservative payout policies. Haushalter, Klasa and Maxwell (2007) study industry interdependence and show that firms in concentrated industries face greater predation risk and therefore hold more cash (and use more derivatives). Fresard (2010) argues that when faced with increased competitive pressures, firms with higher 
cash holdings are able to gain market share at the expense of rival firms. More recently, Fresard and Valta (2013) use import tariff data and show that firms adopt more conservative investment policies, i.e. reduce capital investment and $R \& D$ following tariff reductions. Similarly, Valta (2012) finds that increased competition increases the cost of bank debt for firms in that industry.

Finally, a third strand of literature that is relevant for my paper studies the association between foreign competition and firm behavior. Haddad and Harrison (1993) find evidence that sectors with high levels of foreign investment have a lower dispersion of productivity levels across firms, moving domestically-owned firms closer to the efficiency frontier. Harrison (1994) argues that trade reforms significantly reduce price-cost margins by increasing the level of competition in an industry. Fernandes (2007) examines trade policies in Colombia and finds that trade liberalization improves plant productivity, especially for plants in less competitive industries.

In this paper, I study the impact of foreign competition on the acquisition activity of firms. To survive industry shocks, firms typically use several modes of restructuring including downsizing, layoffs, diversification as well as acquisitions (Kang and Shivdasani (1997)). Given that firms use acquisitions to respond to industry level shocks (Mitchell and Mulherin (1996), Mulherin and Boone (2000), and Andrade and Stafford (2004)), it follows that domestic firms will be more likely to make acquisitions to respond to increased competition from foreign firms. This leads to the main hypothesis stated in alternative form:

H1: Firms' propensities to make acquisitions increase in response to greater foreign competition. 
I use decreases in import tariffs as a measure of increased foreign competition to empirically test this hypothesis. I predict a positive association between the likelihood of making acquisitions and decreases in import tariffs. Further, if these acquisitions in response to increased foreign competition are driven by motives of efficiency gains, one should observe that firms that are more likely to gain from operating efficiencies post-merger are more likely to make acquisitions. Therefore, I predict that firms with lower R\&D, higher capital-to-labor ratio, higher gross margins, and single segment firms are more likely to acquire when faced with increased foreign competition.

When faced with increased foreign competition, only firms that have the resources and ability to respond through acquisitions should be observed to be doing so. Thus, I predict that the positive association between acquisition likelihood and tariff cuts will be more pronounced for financially unconstrained firms and in times of higher capital liquidity.

\section{Sample and Methodology}

\subsection{Sample Construction}

Data on acquisitions are obtained from SDC. Consistent with prior literature, I keep only completed deals excluding divestitures. I drop observations where the bidder held more than $50 \%$ stake in the target company prior to the acquisition. To ensure that the results are not driven by a large number of transactions with insignificant deal values, I drop 318 observations with a deal value of less than $\$ 5$ million and 30 observations where the acquirer holds less than a 100\% 
stake in the target firm post-acquisition ${ }^{8}$. Similar to Harford (1999) I define the dependent variable as a binary variable that takes a value of one if there is an acquisition in that year by a given firm. I merge the tariff data and the acquisition sample to fundamental data from Compustat. The main model contains 41,417 observations with 1,986 acquisitions spanning 22 different industries at the 3 digit NAICS level. Table 2 presents descriptive statistics. The mean probability of acquisition likelihood for my sample is $4.8 \%$. Approximately $20 \%$ of the industryyears in the sample face a $0.5 \%$ tariff cut, while $15 \%(10.9 \%)$ industry-years undergo a $1 \%$ $(1.5 \%)$ tariff reduction.

\subsection{Measurement of Foreign Competition}

I measure increases in foreign competition within an industry using decreases in import tariffs. I gather data on import tariffs at the 6-digit NAICS level from the United States International Trade Commission's (USITC) website. The website allows interactive data download of information on import values as well as duties at the industry-year level and by country of import. Since this study uses decreases in import tariffs as a measure of an increase in foreign competition, I need tariff data at the industry-year level only. Hence, I download the import duty value by industry-year, aggregated across all countries. Within each industry, I calculate the change in import tariff as the percentage change in duty over the prior year. The primary independent variable is a binary variable that takes a value of one if the decrease in tariff is greater than 50 basis points $(0.5 \%)$. Alternatively, I also define binary variables that take a value of one for more than $1 \%$ and $1.5 \%$ tariff cuts, respectively.

\footnotetext{
${ }^{8}$ Prior literature typically excludes deals where the bidder held more than $50 \%$ in the target firm prior to the deal or where the bidder. For example, see Moeller, Schlingemann and Stulz (2005). Results are robust to inclusion of these 30 observations.
} 
Fresard (2010), Valta (2012), as well as Fresard and Valta (2013) use tariff data compiled by Feenstra, Romalis and Schott (2002). Similarly, Xu (2011) uses the same database to compute the ad valorem equivalent of complete Most Favored Nations (MFN) tariff rates from 1989 to 2001. This database is available from NBER's website. However, the data from the USITC website allows one to extend the sample period to more recent years. From this website, I obtain tariff data from 1997 to 2010 for 341 different industries, spanning the agriculture, mining, manufacturing, and publishing industries. Table 3 provides a breakup of average tariff changes by industries at the 3 digit NAICS level.

It must be mentioned here that USITC uses SIC as the basis of industry classification prior to 1997 and NAICS classification beginning from 1997. Using a sample period from before 1997 would entail using a concordance file to match the SIC to the corresponding NAICS codes. However, the match between the two industry classification systems is not one-to-one. To avoid introducing noise into the data by converting SIC industry classification to NAICS based classification, I restrict the sample period to begin in 1997.

\subsection{Model}

I use a linear probability model to examine the relation between likelihood of acquisition and increase in foreign competition. I control for other factors recognized by prior studies as determinants of acquisition likelihood. The control variables include size, net working capital, return on assets, level of cash holdings, $\mathrm{R} \& \mathrm{D}$ expense, debt-to-equity ratio, asset turnover ratio, and market-to-book ratio. Detailed variable definitions are provided in Table 1. I include firm and year fixed effects in all my tests. The firm fixed effects control for unobserved time invariant 
firm- specific characteristics while year fixed effects control for variations across years. Standard errors are corrected for heteroskedasticity and clustered at the firm level.

\section{Empirical Results}

This section discusses the empirical results from testing the hypothesis that firms are more likely to make acquisitions in response to increased foreign competition. If firms do indeed make acquisitions in response to a change in industry competition structure, then a decrease in import tariffs should be associated with an increase in acquisition likelihood. Consistent with my hypothesis, Table 4 indicates that intensification of industry competition, as measured by a decrease in import tariff, is associated with a $1.5 \%$ to $2.3 \%$ increase in the likelihood of firms within that industry making an acquisition. In terms of economic significance, this finding implies that a $0.5 \%$ decrease in import tariffs results in firms within that industry being approximately $31 \%$ more likely to make an acquisition compared to the average firm in the sample (0.015/0.048). Columns 2 and 3 indicate that following a $1 \%$ and $1.5 \%$ decrease in import tariffs, firms within that industry are $39.5 \%$ and $48 \%$ more likely to make an acquisition vis-à-vis the average firm in the sample, respectively. The likelihood of making an acquisition monotonically increases with the magnitude of tariff decreases, indicating that the increase in firms' propensities to make an acquisition can indeed be attributed to the intensification of industry competition. Overall, these results are consistent with the hypothesis that firms are more likely to make acquisitions in response to increased competition.

I also run logit regressions to check the robustness of these results and find that firms that face tariff decreases are $25 \%$ to $45 \%$ more likely to make acquisitions. However, logit regression in Stata uses Maximum Likelihood Estimation (MLE) with dummy variables for fixed effects, 
which gives rise to the incidental parameters problem (Neyman and Scott (1948)). Further, a significant number of observations that are not time variant in my sample are dropped in the logit regressions. Specifically, Stata drops all firms that either never made an acquisition, or made an acquisition each year in the sample period. This results in a sample size of 9389 firm-year observations for the logit model. The marginal effects from the logit regressions are presented in Table A1 in the Appendix.

\subsection{Reverse Causality}

One potential concern is that the above tests could suffer from reverse causality. For example, mergers between a few firms within an industry could result in a reduction in competition, in turn inducing the USITC to reduce import tariffs to induce foreign firms to enter the domestic market. I test the association between acquisition likelihood and the timing of a tariff decrease for evidence of causal relation. If reverse causality were an issue, the likelihood of making an acquisition should increase in the years prior to tariff reduction. Table 5 presents results of this analysis. TARIFF DECREASE DUMMY $\mathrm{t}_{\mathrm{t}+1}$ is an indicator variable that takes a value of 1 for the year immediately before tariff decreases. A significant positive coefficient on this variable would imply an increased likelihood of acquisition by firms in the year prior to the tariff cut. TARIFF DECREASE DUMMY ${ }_{\mathrm{t}}$ is an indicator variable that takes a value of 1 for the years of tariff reduction and TARIFF DECREASE DUMMY $\mathrm{t}_{\mathrm{t}-1}$ takes a value of 1 for the years immediately following a tariff decrease.

In Columns 1 and 3, I find that the probability of making an acquisition is not significantly higher in the year prior to the tariff reduction. Column 2 indicates that firms' propensities to make acquisitions increase significantly in the year of and the year after a tariff decrease. Overall, the findings in Table 5 that firms' propensities of making an acquisition 
increase only the years of and following a tariff cut and not in the year before suggest that the association is unlikely to be driven by reverse causality.

\subsection{Likelihood of Acquisition and Post-Acquisition Efficiency Gains}

In this section I explore the motives for firms to acquire in response to increased foreign competition by examining the cross sectional variations in acquisition probability. The literature on "make-or-buy" decisions suggests that in order to compete and survive, firms either innovate internally or acquire firms with high innovation (e.g. Blonigen and Taylor (2000)). To the extent that innovation and acquisition are substitutes, firms with lower innovation will be more likely to make acquisitions when import tariffs decrease. Consistent with this argument, I find that the positive association between tariff decreases and the likelihood of acquisitions is more pronounced for firms with lower R\&D expenses and for firms in low innovation industries. I measure firm innovation using $R \& D$ expense as well as a binary variable for if the firm is in an innovative industry. Hall, Jaffe and Trajtenberg (2001) use six technological categories to capture innovation. Following their classification, I define innovative industries to include Chemicals and Allied Products (SIC 28), Industrial and Commercial Machinery and Computer Equipment (SIC 35), Electronic, Electrical Equipment \& Components other than Computer Equipment (SIC 36) and Communications (SIC 48). Column 2 of Table 6 shows that firms in less innovative industries are more likely to make acquisitions in response to a tariff decrease than firms in more innovative industries. These findings suggest that firms respond to increased foreign competition by making strategic acquisitions that could help them compete better in the product market.

Next, I investigate the synergy effects of these acquisitions. Bradley, Desai and Kim (1988) argue that merging firms gain from economies of scale as well as redeployment of assets 
to more valuable uses. Devos, Kadapakkam and Krishnamurthy (2009) provide examples of operating improvements post-merger. For example, they cite reduced operating costs and/or capital investments as a potential source of post-merger gains. These gains are more valuable to firms with higher capital investments, since these firms will be able to eliminate duplication of capital investments following acquisitions. If firms indeed respond to increased foreign competition by restructuring to improve production efficiencies, then firms with a higher proportion of capital costs relative to labor costs should be more likely to make acquisitions in response to a tariff decrease. Using the labor-to-capital ratio as an inverse measure of relative capital investment, I find that within industries that face a tariff decrease, firms with a lower labor-to-capital ratio are more likely to make acquisitions.

Multi-segment firms may be able to offset any reduction in cash flows resulting from increased foreign competition with cash flows from other segments that might be more profitable. Since single segment firms are undiversified in their exposure to changes in competition in that industry, such firms have greater incentives to respond to increased foreign competition. Column 4 of Table 6 reports results to support this hypothesis. I find that following a tariff decrease, single segment firms are more likely to make acquisitions.

Drawing on theories of firm scope, Maksimovic and Phillips (2001) predict that in times of industry expansion, more productive firms tend to acquire assets from less productive firms since a more productive firm will gain more value from the assets it controls. Extending their argument, firms with higher ex-ante operating efficiency will be better positioned, and therefore more likely, to make acquisitions in response to increased foreign competition. I use gross margin as a measure of operating efficiency, following Piotroski (2000), and Piotroski and So (2012). Consistent with the above prediction, I find that within industries that face a tariff cut, 
firms with higher gross margins in the years of tariff reduction are more likely to make acquisitions.

Overall, these results suggest that when faced with increased foreign competition, the firms that stand to gain more by acquiring are the ones that are more likely to make acquisitions. The findings are consistent with the argument that firms use mergers and acquisitions as a medium to respond to an increase in foreign competition by attempting to improve operating efficiencies.

The significant coefficients on the interaction variables also lend support to the argument that the positive association between tariff decrease and likelihood of acquisition is unlikely to be driven by omitted variables. For an omitted variable to explain the main results in Table 4 , the variable will have to be uncorrelated with all control variables while being correlated with the interaction variables (Agrawal and Matsa (2013)).

\subsection{Financial Constraints and Likelihood of Acquisition}

I next examine the association between a tariff cut and the likelihood of acquisition by financially constrained firms. Firms need to have the wherewithal to be able to respond to the increased competition. When faced with increased competition, financially constrained firms will probably not be in a position to react by acquiring other firms. On the other hand, firms with lower financial constraints will have access to sufficient capital to respond to changes in industry competition through the mergers and acquisitions channel. Table 7 presents results of this analysis using several measures of financial constraints. Consistent with my prediction, I find that firms with lower z-scores are less likely to make acquisitions in response to a tariff cut. 
Columns 2 and 3 show that firms with bond ratings and investment grade bond ratings are more likely to make acquisitions in response to tariff decreases.

Finally, following Harford (2005), I use the C\&I spread as an indicator of market liquidity. Harford (2005) argues that merger waves are clustered in periods of low transaction costs and high capital liquidity. Thus, firms should be able to respond to increased foreign competition through acquisitions to a greater extent in periods of high capital liquidity. In Column 4 of Table 7, I find a significant negative association between probability of acquisition and the interaction of tariff decrease dummy variable with C\&I spread. Overall, the Table 7 results are consistent with the prediction that the increased acquisition activity in response to increased foreign competition is more pronounced for firms that have access to sufficient capital to make such acquisitions. These findings are also consistent with availability of capital being an important consideration for firms that acquire in response to increased foreign competition.

\subsection{Announcement Returns}

In this section, I analyze whether the increased acquisition activity associated with tariff decrease is indeed an optimal response by firms. Literature abounds on studies using announcement returns to gauge shareholders' reaction to merger announcements ${ }^{9}$. For example, Dodd (1980), Bouwman, Fuller, Nain (2009), find negative abnormal returns to acquirer shareholders. On the other hand, studies like Asquith (1983) and Asquith, Bruner and Mullins (1983) document positive abnormal returns to bidder shareholders. More recently Netter, Stegemoller and Wintoki (2011) use lesser restrictions on the acquisition sample and show that bidder shareholders on average gain in the 3 days surrounding merger announcements. If

\footnotetext{
${ }^{9}$ See Jensen and Ruback (1983), Jarrell, Brickley and Netter (1988) and Andrade, Mitchell and Stafford (2001) for review of these studies.
} 
increased takeover activity in response to increased competition is indeed an optimal response by firms, then the announcement of such acquisitions should be associated with a positive shareholder reaction. I examine the cumulative abnormal returns in the five day window surrounding acquisition announcement. Daily abnormal returns are calculated in excess of the market model. Results of this analysis are presented in Table 8. Column 1 presents results of univariate analysis while Column 2 includes control variables consistent with prior studies. I find that acquisition announcements in response to tariff decreases are associated with around $1.3 \%$ greater abnormal returns to acquirers in the five days surrounding the announcement.

To control for any potential selection bias, I also use Heckman selection model to examine the impact of tariff decrease on announcement returns conditional on firms making an acquisition. Column 3 presents second stage regression results. I find that conditional on a firm making an acquisition, a decrease in import tariff is associated with $2.9 \%$ higher abnormal returns. Overall, the results in Table 8 suggest that acquisitions made in response to increased foreign competition are seen as favorable responses by acquirer shareholders. This lends further support to the main findings of this paper that firms are more likely to make acquisitions to improve efficiency to respond to increased foreign competition.

\subsection{Foreign Targets}

Next, I examine whether domestic firms are likely to acquire foreign targets in response to increased foreign competition. The findings so far suggest that firms acquire in response to increased foreign competition to improve efficiency. One way of achieving operational efficiency is to acquire foreign targets that provide access labor and materials at lower costs (Dunning (1998), Bertrand, Muchhielli and Zitouna (2007)). To the extent that firms respond to decrease in tariffs by trying to take advantage of cost efficiencies, one should observe 
an increase in the probability of domestic firms acquiring foreign targets ${ }^{10}$. To test this hypothesis, I use a sample of acquisitions of foreign targets by domestic firms. Table 9 shows that decrease in import tariffs is positively associated with the firms' likelihood of acquiring foreign targets. This is consistent with my prediction that domestic firms respond to increase in foreign competition by acquiring targets in foreign markets that enable them to take advantage of lower costs of production.

Further, these results should be driven by larger domestic firms. Larger firms within an industry are probably more likely to already be multinational firms, and will likely have better access to capital markets and other resources required to engage in M\&A activity. Thus, I predict that the interaction between the tariff decrease dummy and acquirer size will be positively associated with the probability of acquisitions. In Column 4, I find evidence to support this prediction, suggesting that domestic firms are more likely to acquire foreign firms when faced with increased foreign competition to gain access to other markets. Together with the main results, these findings indicate that firms use acquisitions as a device to gain operational efficiencies to help them survive the increased foreign competition.

\section{Conclusion}

I examine whether firms are more likely to make acquisitions in response to changes in industry competitive structure. Using decreases in import tariffs as an exogenous increase in foreign competition, I find that firms within an industry are more likely to make acquisitions in

\footnotetext{
${ }^{10}$ Domestic firms could also be acquiring foreign targets to diversify into foreign markets since the domestic markets are now more competitive than before (e.g. Horn and Persson (2001), Bjorvatn (2004)). In either case, the empirical implications are the same.
} 
response to an intensification of foreign competition. Further, the likelihood of making acquisitions monotonically increases with the magnitude of tariff reductions.

I show that the significant positive association between tariff cuts and increased probability of acquisitions holds only in the years of and following the tariff decreases, suggesting that the results are unlikely to be driven by reverse causality. Cross sectional tests show that firms that stand to gain more by acquiring are more likely to make acquisitions in response to increased competition. Specifically, the likelihood of making acquisitions in response to tariff cuts is higher for single segment firms, and firms with lower $R \& D$, higher gross margin, and higher capital-to-labor ratios. I also find that the positive relation between tariff decreases and likelihood of acquisitions is weaker for financially constrained firms, suggesting that access to capital is an important factor that drives takeover activity following increased competition.

Announcement returns tests show that shareholders of firms announcing such acquisitions in response to tariff cuts experience positive abnormal returns. These findings are consistent with the argument that firms undertake corporate mergers to improve efficiency in order to enable them to face the increased competition.

Finally, I also find that when faced with greater competition from foreign rivals, domestic firms are more likely to acquire targets in foreign markets to take advantage of lower labor and materials costs. Further, I provide evidence that larger domestic firms that have the resources at their disposal are more likely to diversify into foreign markets compared to their smaller counterparts. 
The evidence has implications for our understanding of the M\&A literature. Researchers are divided in their opinion of whether mergers are an optimal outcome of firms seeking to achieve efficiency gains or a result of managers taking advantage of market inefficiencies. This paper documents evidence that acquisitions provide a medium for firms to restructure in response to industry-level shocks. Moreover, these restructuring activities seem to be driven by firms seeking to obtain efficiency gains that allow them to compete against other firms in the industry and to survive industry shocks. 


\section{Table 1: Variable Descriptions}

Variable Name

SDC Variables

\section{ACQFLAG}

\section{ALL CASH DEAL}

\section{ALL STOCK DEAL}

REL TRANSACTION VALUE

\section{PUBLIC TARGET DUMMY}

\section{SUBSIDIARY TARGET DUMMY}

Import Tariffs

TARIFF DECREASE DUMMY $(0.5 \%)$

TARIFF DECREASE DUMMY (1\%)

TARIFF DECREASE DUMMY (1.5\%)
Variable Description

Compustat Definition

Binary variable that takes a value of 1 if a firm made an acquisition in year t, 0 otherwise. Data on acquisition is from SDC.

Binary variable that takes a value of 1 if the acquisition is $100 \%$ financed through cash, 0 otherwise

Binary variable that takes a value of 1 if the acquisition is $100 \%$ financed through stock, 0 otherwise

Value of acquisition deal scaled by lag market value of equity of bidder

Binary variable that takes a value of 1 if the target is a public firm, 0 otherwise

Binary variable that takes a value of 1 if the target is a subsidiary company, 0 otherwise

Binary variable that takes a value of 1 if an industry faced a tariff cut of $0.5 \%$ or more. Industry is defined as the 6 digit NAICS level. Data on import tariffs is from the USITC website.

Binary variable that takes a value of 1 if an industry faced a tariff cut of $1 \%$ or more. Industry is defined as the 6 digit NAICS level. Data on import tariffs is from the USITC website.

Binary variable that takes a value of 1 if an industry faced a tariff cut of $1.5 \%$ or more. Industry is defined as the 6 digit NAICS level. Data on import tariffs is from the USITC website. 
NET WORKING CAPITAL

ROA

CASH

$\mathrm{R} \& \mathrm{D}$

ASSET TURNOVER

MARKET-TO-BOOK

D/E RATIO

LAB/CAP RATIO

GROSS MARGIN

Z SCORE

BOND RATING

INV BOND RATING
Sum of inventory, accounts receivable and cash and marketable securities less accounts payable and debt in current liabilities. Individual values of inventory, receivables, payables, cash and debt in current liabilities with missing values are set to 0 . I further scale the net working capital variable by 1000 so as to make the regression coefficients meaningful.

Earnings before interest and taxes scaled by total assets

Cash and marketable securities scaled by total assets

R\&D expense divided by total assets. The value of $R \& D$ expense is set to 0 if missing. Alternate definitions include R\&D expense scaled by net sales.

Ratio of net sales to total assets

Ratio of market value of assets to book value of assets

Ratio of book value of long term debt to market value of equity

Ratio of number of employees to the value of net property, plant and equipment

Ratio of sales minus cost of goods sold to net sales

Measure of probability of bankruptcy.

Binary variable that takes a value of 1 if the firm has an S\&P Domestic Long Term Issuer Credit Rating for year t, 0 otherwise

Binary variable that takes a value of 1 if the S\&P Long Term Issuer Credit Rating is BBB- or better, 0 otherwise invt + artfs + che - ap - dlc

ebit/at

che/at

$\mathrm{xrd} / \mathrm{at}$

sale/at

$($ at - ceq + prcc_f*csho $) /$ at

$(\mathrm{dltt}+\mathrm{dlc}) /(\mathrm{csho} *$ prcc_f $)$

emp/ppent

(sale - cogs)/sale

$3.3 *($ ebit/at $)+($ sale/at $)+$ $1.4 *($ re $/ a t)+1.2 *(($ act-lct $) /$ at $)+$ $0.6 *(($ prec_f $*$ csho $)+$ pref $) / \mathrm{lt})$ 
Quarterly Commercial and Industrial Loan Spread. Since this data is available on 


\section{Table 2: Summary Statistics}

TARIFF DECREASE DUMMY takes a value of 1 for industry-years that experienced a tariff decrease. Model 1 uses a $0.5 \%$ tariff decrease as the independent variable, while Models 2 and 3 use 1\% and 1.5\% tariff decreases respectively. SIZE is defined as the natural logarithm of total assets. NET WORKING CAPITAL is measured as the sum of inventory, accounts receivables and cash less accounts payable and debt in current liabilities. ROA is ratio of EBIT to total assets. CASH is defined as the level of cash and cash equivalents scaled by total assets while $R \& D$ is $R \& D$ expenses scaled by total assets. D/E RATIO is measured as the ratio of long term debt to market value of equity; ASSET_TURNOVER is net sales scaled by total assets. MARKET-TO-BOOK is the ratio of market value to book value of assets.

\begin{tabular}{lcccccc} 
& Count & Mean & Median & SD & P25 & P75 \\
\hline ACQFLAG & 41417 & 0.048 & 0.000 & 0.214 & 0.000 & 0.000 \\
TARIFF DECREASE DUMMY (0.5\%) & 41417 & 0.202 & 0.000 & 0.401 & 0.000 & 0.000 \\
TARIFF DECREASE DUMMY (1\%) & 41417 & 0.151 & 0.000 & 0.358 & 0.000 & 0.000 \\
TARIFF DECREASE DUMMY (1.5\%) & 41417 & 0.109 & 0.000 & 0.311 & 0.000 & 0.000 \\
SIZE & 41417 & 4.729 & 4.665 & 2.534 & 3.094 & 6.393 \\
NET WORKING CAPITAL & 41417 & 0.156 & 0.015 & 1.224 & 0.000 & 0.084 \\
ROA & 41417 & -0.201 & 0.029 & 0.789 & -0.172 & 0.102 \\
CASH & 41417 & 0.248 & 0.155 & 0.253 & 0.038 & 0.397 \\
R\&D & 41417 & 0.115 & 0.039 & 0.210 & 0.000 & 0.134 \\
ASSET TURNOVER & 41417 & 0.910 & 0.811 & 0.660 & 0.436 & 1.224 \\
MARKET-TO-BOOK & 41417 & 3.275 & 1.693 & 5.708 & 1.163 & 2.940 \\
D/E RATIO & 41417 & 0.611 & 0.095 & 1.860 & 0.002 & 0.403 \\
\hline
\end{tabular}


Table 3: Average Change in Import Tariffs by Industry

This table reports the average change in import tariffs at the 3 digit NAICS level.

\begin{tabular}{|c|c|c|c|}
\hline $\begin{array}{l}3 \text { digit } \\
\text { NAICS }\end{array}$ & Description & $\begin{array}{l}\text { \# of firm- } \\
\text { years }\end{array}$ & $\begin{array}{c}\text { Average change in } \\
\text { import tariff }\end{array}$ \\
\hline 111 & Crop Production & 205 & -0.001 \\
\hline 113 & Forestry and Logging & 30 & -0.016 \\
\hline 211 & Oil and Gas Extraction & 3237 & -0.045 \\
\hline 212 & Mining (Except Oil and Gas) & 1110 & -0.018 \\
\hline 311 & Food Manufacturing & 1084 & 0.101 \\
\hline 313 & Textile Mills & 197 & -0.069 \\
\hline 315 & Apparel Manufacturing & 313 & 0.045 \\
\hline 321 & Wood Product Manufacturing & 334 & 0.053 \\
\hline 322 & Paper Manufacturing & 861 & -0.047 \\
\hline 323 & Printing and Relate Support Activities & 233 & -0.115 \\
\hline 324 & Petroleum and Coal Products Manufacturing & 629 & 0.026 \\
\hline 325 & Chemical Manufacturing & 7512 & 0.020 \\
\hline 326 & Plastics and Rubber Products Manufacturing & 821 & 0.084 \\
\hline 327 & Nonmetallic Mineral Product Manufacturing & 558 & -0.010 \\
\hline 331 & Primary Metal Manufacturing & 1043 & -0.036 \\
\hline 332 & Fabricated Metal Product Manufacturing & 1043 & 0.068 \\
\hline 333 & Machinery Manufacturing & 3650 & -0.019 \\
\hline 334 & $\begin{array}{l}\text { Computer and Electronic Product Manufacturing } \\
\text { Electrical Equipment, Appliance, and Component }\end{array}$ & 12621 & -0.096 \\
\hline 335 & Manufacturing & 1391 & 0.043 \\
\hline 337 & Furniture and Related Product Manufacturing & 342 & -0.077 \\
\hline 339 & Miscellaneous Manufacturing & 2767 & -0.037 \\
\hline 511 & Publishing Industries (Except Internet) & 5630 & -0.202 \\
\hline
\end{tabular}


Table 4: Foreign Competition and Likelihood of Acquisitions

Dependent variable is the likelihood of acquisition. TARIFF DECREASE DUMMY takes a value of 1 for industry-years that experienced a tariff decrease. Model 1 uses a $0.5 \%$ tariff decrease as the independent variable, while Models 2 and 3 use $1 \%$ and $1.5 \%$ tariff decreases respectively. SIZE is defined as the natural logarithm of total assets. NET WORKING CAPITAL is measured as the sum of inventory, accounts receivables and cash less accounts payable and debt in current liabilities. ROA is ratio of EBIT to total assets. CASH is defined as the level of cash and cash equivalents scaled by total assets while R\&D is R\&D expenses scaled by total assets. D/E RATIO is measured as the ratio of long term debt to market value of equity; ASSET_TURNOVER is net sales scaled by total assets. MARKET-TO-BOOK is the ratio of market value to book value of assets. Standard errors are clustered at the firm level (t-statistics are in parentheses). All models include year and firm fixed effects. $*, * *$, and $* * *$ denote significance at the $10 \%, 5 \%$, and $1 \%$ level, respectively.

\begin{tabular}{|c|c|c|c|}
\hline \multirow[t]{2}{*}{ Dependent Variable } & \multicolumn{3}{|c|}{ Likelihood of Acquisition } \\
\hline & $(1)$ & (2) & (3) \\
\hline TARIFF DECREASE DUMMY $(0.5 \%)$ & $\begin{array}{c}0.015 * * * \\
(3.32)\end{array}$ & & \\
\hline TARIFF DECREASE DUMMY (1\%) & & $\begin{array}{c}0.019 * * * \\
(3.31)\end{array}$ & \\
\hline TARIFF DECREASE DUMMY (1.5\%) & & & $\begin{array}{c}0.023 * * \\
(2.41)\end{array}$ \\
\hline SIZE & $\begin{array}{c}0.018 * * * \\
(7.66)\end{array}$ & $\begin{array}{c}0.018 * * * \\
(7.69)\end{array}$ & $\begin{array}{c}0.018 * * * \\
(7.72)\end{array}$ \\
\hline NET WORKING CAPITAL & $\begin{array}{l}0.001 \\
(0.51)\end{array}$ & $\begin{array}{l}0.001 \\
(0.50)\end{array}$ & $\begin{array}{l}0.001 \\
(0.51)\end{array}$ \\
\hline ROA & $\begin{array}{l}0.002 \\
(0.97)\end{array}$ & $\begin{array}{l}0.002 \\
(0.93)\end{array}$ & $\begin{array}{l}0.002 \\
(1.10)\end{array}$ \\
\hline $\mathrm{CASH}$ & $\begin{array}{c}-0.052 * * * \\
(-7.00)\end{array}$ & $\begin{array}{c}-0.052 * * * \\
(-6.99)\end{array}$ & $\begin{array}{c}-0.052 * * * \\
(-6.96)\end{array}$ \\
\hline $\mathrm{R} \& \mathrm{D}$ & $\begin{array}{c}0.013 * \\
(1.90)\end{array}$ & $\begin{array}{c}0.013 * \\
(1.91)\end{array}$ & $\begin{array}{c}0.013 * \\
(1.91)\end{array}$ \\
\hline D/E RATIO & $\begin{array}{c}-0.003 * * * \\
(-5.65)\end{array}$ & $\begin{array}{c}-0.003 * * * \\
(-5.67)\end{array}$ & $\begin{array}{c}-0.003 * * * \\
(-5.65)\end{array}$ \\
\hline ASSET TURNOVER & $\begin{array}{c}-0.013 * * * \\
(-5.02)\end{array}$ & $\begin{array}{c}-0.013 * * * \\
(-4.99)\end{array}$ & $\begin{array}{c}-0.013 * * * \\
(-5.01)\end{array}$ \\
\hline MARKET-TO-BOOK & $\begin{array}{c}0.002 * * * \\
(7.18)\end{array}$ & $\begin{array}{c}0.002 * * * \\
(7.17)\end{array}$ & $\begin{array}{c}0.002 * * * \\
(7.37)\end{array}$ \\
\hline CONSTANT & $\begin{array}{l}-0.013 \\
(-0.97)\end{array}$ & $\begin{array}{l}-0.017 \\
(-1.23)\end{array}$ & $\begin{array}{l}-0.022 \\
(-1.35)\end{array}$ \\
\hline R SQUARED & 0.010 & 0.010 & 0.010 \\
\hline ADJUSTED R SQUARED & 0.009 & 0.009 & 0.009 \\
\hline $\mathrm{N}$ & 41417 & 41417 & 41417 \\
\hline
\end{tabular}


Table 5: Timing of the Relation between Likelihood of Acquisitions and Tariff Decreases

TARIFF DECREASE DUMMY takes a value of 1 for industry-years that experienced a tariff decrease of $0.5 \%$ or more. TARIFF DECREASE DUMMY ${ }_{t+1}$ takes a value of 1 for the year immediately before a tariff decrease of $0.5 \%$ whereas TARIFF DECREASE DUMMY $\mathrm{t}_{\mathrm{t}-1}$ takes a value of 1 for the year immediately after a tariff decrease of 0.5. SIZE is defined as the natural logarithm of total assets. NET WORKING CAPITAL is measured as the sum of inventory, accounts receivables and cash less accounts payable and debt in current liabilities. ROA is ratio of EBIT to total assets. CASH is defined as the level of cash and cash equivalents scaled by total assets while $R \& D$ is $R \& D$ expenses scaled by total assets. D/E RATIO is measured as the ratio of long term debt to market value of equity; ASSET_TURNOVER is net sales scaled by total assets. MARKET-TO-BOOK is the ratio of market value to book value of assets. Standard errors are clustered at the firm level (t-statistics are in parentheses). All models include year and firm fixed effects. *, **, and *** denote significance at the $10 \%, 5 \%$, and $1 \%$ level, respectively.

\begin{tabular}{|c|c|c|c|}
\hline \multirow[t]{2}{*}{ Dependent Variable } & \multicolumn{3}{|c|}{ Likelihood of Acquisition in Year $t$} \\
\hline & (1) & (2) & (3) \\
\hline TARIFF DECREASE DUMMY t-1 & & $\begin{array}{c}0.010^{* *} \\
(2.34)\end{array}$ & $\begin{array}{c}0.013 \text { *** } \\
(2.81)\end{array}$ \\
\hline TARIFF DECREASE DUMMY $(0.5 \%)$ & $\begin{array}{c}0.016^{* * * *} \\
(3.18)\end{array}$ & $\begin{array}{c}0.014 * * * \\
(2.82)\end{array}$ & $\begin{array}{c}0.014 * * * \\
(2.62)\end{array}$ \\
\hline TARIFF DECREASE DUMMY $\mathrm{t}+1$ & $\begin{array}{l}0.002 \\
(0.49)\end{array}$ & & $\begin{array}{l}0.007 \\
(1.32)\end{array}$ \\
\hline SIZE & $\begin{array}{c}0.020 * * * \\
(6.97)\end{array}$ & $\begin{array}{c}0.018 * * * \\
(6.70)\end{array}$ & $\begin{array}{c}0.020 * * * \\
(6.31)\end{array}$ \\
\hline NET WORKING CAPITAL & $\begin{array}{l}0.001 \\
(0.31)\end{array}$ & $\begin{array}{l}-0.000 \\
(-0.13)\end{array}$ & $\begin{array}{l}-0.001 \\
(-0.43)\end{array}$ \\
\hline ROA & $\begin{array}{l}0.004^{*} \\
(1.90)\end{array}$ & $\begin{array}{l}0.002 \\
(0.95)\end{array}$ & $\begin{array}{l}0.004 \\
(1.57)\end{array}$ \\
\hline $\mathrm{CASH}$ & $\begin{array}{c}-0.058 * * * \\
(-6.34)\end{array}$ & $\begin{array}{c}-0.051 * * * * \\
(-5.95)\end{array}$ & $\begin{array}{c}-0.056^{* * * *} \\
(-5.48)\end{array}$ \\
\hline$R \& D$ & $\begin{array}{c}0.016^{*} \\
(1.96)\end{array}$ & $\begin{array}{l}0.011 \\
(1.40)\end{array}$ & $\begin{array}{l}0.015 \\
(1.58)\end{array}$ \\
\hline D/E RATIO & $\begin{array}{c}-0.004 * * * \\
(-5.31)\end{array}$ & $\begin{array}{c}-0.003 * * * * \\
(-4.78)\end{array}$ & $\begin{array}{c}-0.003 * * * \\
(-4.42)\end{array}$ \\
\hline ASSET TURNOVER & $\begin{array}{c}-0.017 * * * \\
(-4.83)\end{array}$ & $\begin{array}{c}-0.013 \text { **** } \\
(-4.44)\end{array}$ & $\begin{array}{c}-0.016^{* * * *} \\
(-4.33)\end{array}$ \\
\hline MARKET-TO-BOOK & $\begin{array}{c}0.002 * * * \\
(6.67)\end{array}$ & $\begin{array}{c}0.002 * * * \\
(5.79)\end{array}$ & $\begin{array}{c}0.002 * * * \\
(5.24)\end{array}$ \\
\hline CONSTANT & $\begin{array}{l}-0.022 \\
(-1.35)\end{array}$ & $\begin{array}{c}-0.043 * * * \\
(-2.71)\end{array}$ & $\begin{array}{c}-0.054 * * * \\
(-2.82)\end{array}$ \\
\hline R SQUARED & 0.010 & 0.010 & 0.010 \\
\hline ADJUSTED R SQUARED & 0.010 & 0.009 & 0.010 \\
\hline $\mathrm{N}$ & 34394 & 35609 & 29537 \\
\hline
\end{tabular}




\section{Table 6: Likelihood of Acquisitions and Post-Acquisition Efficiency Gains}

TARIFF DECREASE DUMMY takes a value of 1 for industry-years that experienced a tariff decrease of $0.5 \%$ or more. SIZE is defined as the natural logarithm of total assets. NET WORKING CAPITAL is measured as the sum of inventory, accounts receivables and cash less accounts payable and debt in current liabilities. ROA is ratio of EBIT to total assets. CASH is defined as the level of cash and cash equivalents scaled by total assets while R\&D is R\&D expenses scaled by total assets. D/E RATIO is measured as the ratio of long term debt to market value of equity; ASSET_TURNOVER is net sales scaled by total assets. MARKET-TO-BOOK is the ratio of market value to book value of assets. INNOVATIVE IND DUMMY takes a value of 1 for SIC industries 28, 35, 36 and 48, 0 otherwise. GROSS MARGIN is the difference between sales and COGS as a proportion of sales; LAB/CAP RATIO is measured as the ratio of number of employees to the net plant, property and equipment. SINGLE SEGMENT DUMMY is a dummy variable for if a firm operates as a single segment firm, 0 otherwise. Standard errors are clustered at the firm level (t-statistics are in parentheses). All models include year and firm fixed effects. *, **, and *** denote significance at the $10 \%, 5 \%$, and $1 \%$ level, respectively.

\begin{tabular}{|c|c|c|c|c|c|}
\hline \multirow[t]{2}{*}{ Dependent Variable } & \multicolumn{5}{|c|}{ Likelihood of Acquisition } \\
\hline & (1) & (2) & (3) & (4) & (5) \\
\hline TARIFF DECREASE DUMMY (0.5\%) & $\begin{array}{c}0.019 * * * \\
(3.82)\end{array}$ & $\begin{array}{l}0.004 \\
(1.29)\end{array}$ & $\begin{array}{c}0.019 * * * \\
(3.48)\end{array}$ & $\begin{array}{l}-0.033 \\
(-1.41)\end{array}$ & $\begin{array}{c}0.015 * * * \\
(3.33)\end{array}$ \\
\hline R\&D * TARIFF DEC DUMMY & $\begin{array}{c}-0.030 * * * \\
(-3.21)\end{array}$ & & & & \\
\hline INNOVATIVE IND DUMMY & & $\begin{array}{c}0.982 * * * \\
(186.23)\end{array}$ & & & \\
\hline INNOVATIVE IND DUMMY* TARIFF DEC DUMMY & & $\begin{array}{c}-0.011^{*} \\
(-1.86)\end{array}$ & & & \\
\hline LAB/CAP RATIO & & & $\begin{array}{c}0.053 * * * \\
(4.54)\end{array}$ & & \\
\hline LAB/CAP RATIO* TARIFF DEC DUMMY & & & $\begin{array}{c}-0.055^{* * *} * \\
(-2.81)\end{array}$ & & \\
\hline SINGLE SEGMENT DUMMY & & & & $\begin{array}{c}0.011 * \\
(1.74)\end{array}$ & \\
\hline SINGLE SEG DUMMY* TARIFF DEC DUMMY & & & & $\begin{array}{c}0.049 * * \\
(2.05)\end{array}$ & \\
\hline GROSS MARGIN & & & & & $\begin{array}{l}0.000 \\
(0.96)\end{array}$ \\
\hline GROSS MARGIN* TARIFF DEC DUMMY & & & & & $\begin{array}{l}0.000^{*} \\
(1.67)\end{array}$ \\
\hline SIZE & $\begin{array}{c}0.018 * * * \\
(7.71)\end{array}$ & $\begin{array}{c}0.009 * * * \\
(5.04)\end{array}$ & $\begin{array}{c}0.021 * * * \\
(7.74)\end{array}$ & $\begin{array}{c}0.018 * * * \\
(7.68)\end{array}$ & $\begin{array}{c}0.018 * * * \\
(7.64)\end{array}$ \\
\hline NET WORKING CAPITAL & $\begin{array}{l}0.001 \\
(0.51)\end{array}$ & $\begin{array}{l}-0.000 \\
(-0.01)\end{array}$ & $\begin{array}{l}0.001 \\
(0.47)\end{array}$ & $\begin{array}{l}0.001 \\
(0.54)\end{array}$ & $\begin{array}{l}0.001 \\
(0.51)\end{array}$ \\
\hline
\end{tabular}




\begin{tabular}{|c|c|c|c|c|c|}
\hline ROA & $\begin{array}{l}0.002 \\
(0.98)\end{array}$ & $\begin{array}{l}0.001 \\
(0.87)\end{array}$ & $\begin{array}{c}0.004 * * \\
(2.00)\end{array}$ & $\begin{array}{l}0.002 \\
(0.97)\end{array}$ & $\begin{array}{l}0.002 \\
(0.89)\end{array}$ \\
\hline $\mathrm{CASH}$ & $\begin{array}{c}-0.052 * * * \\
(-6.95)\end{array}$ & $\begin{array}{c}-0.030 * * * \\
(-5.34)\end{array}$ & $\begin{array}{c}-0.063 * * * \\
(-7.31)\end{array}$ & $\begin{array}{c}-0.052 * * * \\
(-6.99)\end{array}$ & $\begin{array}{c}-0.052 * * * \\
(-6.95)\end{array}$ \\
\hline ASSET TURNOVER & $\begin{array}{c}-0.013 * * * \\
(-4.94)\end{array}$ & $\begin{array}{c}-0.009 * * * \\
(-4.40)\end{array}$ & $\begin{array}{c}-0.018 * * * \\
(-5.58)\end{array}$ & $\begin{array}{c}-0.014 * * * \\
(-5.08)\end{array}$ & $\begin{array}{c}-0.014 * * * \\
(-5.09)\end{array}$ \\
\hline MARKET-TO-BOOK & $\begin{array}{c}0.002 * * * \\
(7.13)\end{array}$ & $\begin{array}{c}0.001 * * * \\
(5.46)\end{array}$ & $\begin{array}{c}0.002 * * * \\
(6.76)\end{array}$ & $\begin{array}{c}0.002 * * * \\
(7.18)\end{array}$ & $\begin{array}{c}0.002 * * * \\
(7.22)\end{array}$ \\
\hline D/E RATIO & $\begin{array}{c}-0.003 * * * \\
(-5.60)\end{array}$ & $\begin{array}{c}-0.002 * * * \\
(-4.86)\end{array}$ & $\begin{array}{c}-0.004 * * * \\
(-5.98)\end{array}$ & $\begin{array}{c}-0.003 * * * \\
(-5.63)\end{array}$ & $\begin{array}{c}-0.003 * * * \\
(-5.65)\end{array}$ \\
\hline$R \& D$ & $\begin{array}{c}0.019 * * * \\
(2.81)\end{array}$ & $\begin{array}{c}0.008^{*} \\
(1.75)\end{array}$ & $\begin{array}{c}0.022 * * * \\
(2.84)\end{array}$ & $\begin{array}{c}0.013^{*} \\
(1.94)\end{array}$ & $\begin{array}{l}0.013^{*} \\
(1.94)\end{array}$ \\
\hline CONSTANT & $\begin{array}{l}-0.015 \\
(-1.15)\end{array}$ & $\begin{array}{l}0.008 \\
(0.76)\end{array}$ & $\begin{array}{l}-0.023 \\
(-1.47)\end{array}$ & $\begin{array}{l}-0.025^{*} \\
(-1.72)\end{array}$ & $\begin{array}{l}-0.012 \\
(-0.93)\end{array}$ \\
\hline R SQUARED & 0.010 & 0.417 & 0.011 & 0.010 & 0.010 \\
\hline ADJUSTED R SQUARED & 0.010 & 0.417 & 0.011 & 0.010 & 0.009 \\
\hline $\mathrm{N}$ & 40682 & 40682 & 37756 & 41417 & 40682 \\
\hline
\end{tabular}


Table 7: Likelihood of Acquisitions by Financially Constrained Firms

TARIFF DECREASE DUMMY takes a value of 1 for industry-years that experienced a tariff decrease of $0.5 \%$ or more. SIZE is defined as the natural logarithm of total assets. NET WORKING CAPITAL is measured as the sum of inventory, accounts receivables and cash less accounts payable and debt in current liabilities. ROA is ratio of EBIT to total assets. CASH is defined as the level of cash and cash equivalents scaled by total assets while R\&D is R\&D expenses scaled by total assets. D/E RATIO is measured as the ratio of long term debt to market value of equity; ASSET_TURNOVER is net sales scaled by total assets. MARKET-TO-BOOK is the ratio of market value to book value of assets. Z SCORE is a measure of probability of bankruptcy as defined in Table 1. BOND RATING takes a value of 1 if a firm has a bond rating in year $\mathrm{t}, 0$ otherwise. INV BOND RATING takes a value of 1 for firms that have investment grade bond rating in year $\mathrm{t}$. Standard errors are clustered at the firm level (t-statistics are in parentheses). All models include year and firm fixed effects. *,**, and *** denote significance at the $10 \%, 5 \%$, and $1 \%$ level, respectively.

Dependent Variable

Likelihood of Acquisition

TARIFF DECREASE DUMMY (0.5\%)

(2)

Z SCORE

ZSCORE* TARIFF DEC DUMMY

BOND RATING

BOND RATING* TARIFF DEC DUMMY

INV BOND RATING

INV BOND RATING* TARIFF DEC DUMMY

C\&I SPREAD

C\&I * TARIFF DEC DUMMY

SIZE

NET WORKING CAPITAL

ROA

CASH

ASSET TURNOVER

MARKET-TO-BOOK

D/E RATIO

$R \& D$
$0.015^{* * * *}$

(3.50)

$-0.001 * * *$

$(-5.83)$

$0.000 * * *$

(4.27)

$-0.025^{* *}$

$(-2.49)$

$0.037 * * *$

(2.79)

0.010

(0.70)

$0.039 * *$

(2.03)

(2.76)

(4)

0.070 **

(2.48)

(2.21)

.

$\begin{array}{cccc} & & 0.039 * * & \\ & & (2.03) & \\ & & & \\ & & (2.68) \\ & & & -0.025 * * \\ & & & (-2.05) \\ & & & 0.017 * * * \\ 0.018 * * * & 0.019 * * * & 0.018 * * * & (7.57) \\ (7.74) & (8.23) & (7.63) & 0.001 \\ 0.002 & 0.002 & 0.002 & (0.53) \\ (0.69) & (0.60) & (0.57) & 0.002 \\ 0.002 & 0.001 & 0.002 & (1.00) \\ (1.27) & (0.81) & (1.06) & -0.052 * * * \\ -0.054 * * * & -0.052 * * * & -0.052 * * * & (-7.01) \\ (-7.19) & (-6.92) & (-6.89) & -0.014 * * * \\ -0.014 * * * & -0.013 * * * & -0.014 * * * & (-5.08) \\ (-5.30) & (-5.04) & (-5.12) & (7.12) \\ 0.002 * * * & 0.002 * * * & 0.002 * * * & 0.002 * * * \\ (7.11) & (7.33) & (7.20) & -0.003 * * * \\ -0.003 * * * & -0.003 * * * & -0.003 * * * & (-5.76) \\ (-5.64) & (-5.36) & (-5.62) & 0.012 *\end{array}$




\begin{tabular}{lcccc} 
& $(2.16)$ & $(1.98)$ & $(1.92)$ & $(1.87)$ \\
CONSTANT & -0.013 & -0.015 & -0.014 & $-0.061 * * *$ \\
& $(-0.99)$ & $(-1.13)$ & $(-1.04)$ & $(-2.92)$ \\
R SQUARED & 0.010 & 0.011 & 0.010 & 0.010 \\
ADJUSTED R SQUARED & 0.010 & 0.010 & 0.010 & 0.010 \\
$\mathrm{~N}$ & 41015 & 41410 & 41410 & 41417 \\
\hline
\end{tabular}


Table 8: Announcement Returns to Acquisitions around Tariff Decreases

The dependent variable is the $[-2,2]$ CAR for each acquisition announcement. TARIFF DECREASE DUMMY takes a value of 1 for industry-years that experienced a tariff decrease of $0.5 \%$ or more. SIZE is measured as the natural log of total assets; ROA is ratio of EBIT to total assets. R\&D is R\&D expenses scaled by total assets. D/E RATIO is measured as the ratio of long term debt to market value of equity; MARKET-TO-BOOK is the ratio of market value to book value of assets. ALL CASH DEAL is a binary variable that takes a value 1 if the acquisition was $100 \%$ cash deal while ALL STOCK DEAL takes a value of 1 if the acquisition was completely paid through stocks. REL TRANSACTION VALUE is the deal size scaled by lagged bidder market value of equity. PUBLIC TARGET DUMMY takes a value of 1 if the target is a public company, whereas SUBSIDIARY TARGET DUMMY is a dummy variable for if the target is a subsidiary company. First (not reported) and second stage of the Heckman model include firm and year fixed effects. $*, * *$, and $* * *$ denote significance at the $10 \%$, $5 \%$, and $1 \%$ level, respectively.

\begin{tabular}{|c|c|c|c|}
\hline \multirow[t]{2}{*}{ Dependent Variable } & \multicolumn{2}{|c|}{ CAR $[-2,+2]$} & \multirow[b]{2}{*}{$\begin{array}{l}\text { Second Stage } \\
\text { from } \\
\text { Heckman } \\
\text { model } \\
\end{array}$} \\
\hline & \multicolumn{2}{|c|}{ OLS } & \\
\hline \multirow[t]{2}{*}{ TARIFF DECREASE DUMMY $(0.5 \%)$} & $0.012 * *$ & $0.013^{*}$ & $0.029 * *$ \\
\hline & $(2.14)$ & $(1.68)$ & $(2.45)$ \\
\hline \multirow[t]{2}{*}{ SIZE } & & -0.001 & 0.021 \\
\hline & & $(-0.77)$ & $(1.54)$ \\
\hline \multirow[t]{2}{*}{$\mathrm{R} \& \mathrm{D}$} & & 0.002 & 0.004 \\
\hline & & $(1.41)$ & $(1.04)$ \\
\hline \multirow[t]{2}{*}{ ROA } & & 0.019 & $-0.058^{*}$ \\
\hline & & $(1.19)$ & $(-1.94)$ \\
\hline \multirow[t]{2}{*}{ D/E RATIO } & & -0.003 & $-0.024 * * *$ \\
\hline & & $(-0.74)$ & $(-3.13)$ \\
\hline \multirow[t]{2}{*}{ MARKET-TO-BOOK } & & -0.000 & $0.003^{*}$ \\
\hline & & $(-0.28)$ & $(1.75)$ \\
\hline \multirow[t]{2}{*}{ ALL CASH DEAL } & & $0.012 *$ & 0.009 \\
\hline & & $(1.91)$ & $(1.27)$ \\
\hline \multirow[t]{2}{*}{ ALL STOCK DEAL } & & 0.007 & 0.001 \\
\hline & & $(0.85)$ & $(0.06)$ \\
\hline \multirow[t]{2}{*}{ REL TRANSACTION VALUE } & & $0.021 * * *$ & 0.012 \\
\hline & & $(2.98)$ & $(1.25)$ \\
\hline \multirow[t]{2}{*}{ PUBLIC TARGET DUMMY } & & 0.005 & $-0.023 * * *$ \\
\hline & & $(0.28)$ & $(-2.90)$ \\
\hline \multirow[t]{2}{*}{ SUBSIDIARY TARGET DUMMY } & & $-0.028 * * *$ & 0.001 \\
\hline & & $(-3.91)$ & $(0.02)$ \\
\hline \multirow[t]{2}{*}{ INVERSE MILLS RATIO } & & 0.006 & $1.895^{* *}$ \\
\hline & & $(0.53)$ & $(2.18)$ \\
\hline CONSTANT & 0.001 & 0.009 & $-1.584 * *$ \\
\hline
\end{tabular}


R SQUARED

ADJUSTED R SQUARED

$\mathrm{N}$

$\begin{array}{ccc}(0.26) & (0.43) & (-2.13) \\ 0.002 & 0.020 & 0.070 \\ 0.002 & 0.014 & -0.895 \\ 2058 & 1691 & 1691\end{array}$


Table 9: Likelihood of Acquiring Foreign Targets

The dependent variable is a dummy variable that takes a value of 1 if the firm acquired a foreign target in year $t$. TARIFF DECREASE DUMMY takes a value of 1 for industry-years that experienced a tariff decrease of $0.5 \%$ or more. SIZE is defined as the natural logarithm of total assets. NET WORKING CAPITAL is measured as the sum of inventory, accounts receivables and cash less accounts payable and debt in current liabilities. ROA is ratio of EBIT to total assets. CASH is defined as the level of cash and cash equivalents scaled by total assets while R\&D is R\&D expenses scaled by total assets. D/E RATIO is measured as the ratio of long term debt to market value of equity; ASSET_TURNOVER is net sales scaled by total assets. MARKET-TO-BOOK is the ratio of market value to book value of assets. Standard errors are clustered at the firm level (t-statistics are in parentheses). All models include year and firm fixed effects. $*, * *$, and $* * *$ denote significance at the $10 \%, 5 \%$, and $1 \%$ level, respectively.

\begin{tabular}{|c|c|c|c|c|}
\hline \multirow[t]{2}{*}{ Dependent variable } & \multicolumn{4}{|c|}{ Likelihood of acquiring foreign targets } \\
\hline & (1) & (2) & (3) & (4) \\
\hline TARIFF DECREASE DUMMY (0.5\%) & $\begin{array}{c}0.007 * * * \\
(2.79)\end{array}$ & & & \\
\hline TARIFF DECREASE DUMMY (1\%) & & $\begin{array}{l}0.007^{*} \\
(1.94)\end{array}$ & & \\
\hline TARIFF DECREASE DUMMY (1.5\%) & & & $\begin{array}{l}0.010^{*} \\
(1.85)\end{array}$ & \\
\hline ACQUIRER SIZE* TARIFF DEC DUMMY & & & & $\begin{array}{c}0.002 * * \\
(2.57)\end{array}$ \\
\hline SIZE & $\begin{array}{c}0.006 * * * \\
(6.47)\end{array}$ & $\begin{array}{c}0.006 * * * \\
(6.51)\end{array}$ & $\begin{array}{c}0.007 * * * \\
(6.54)\end{array}$ & $\begin{array}{c}0.006 * * * \\
(6.29)\end{array}$ \\
\hline NET WORKING CAPITAL & $\begin{array}{l}-0.001 \\
(-0.84)\end{array}$ & $\begin{array}{l}-0.001 \\
(-0.85)\end{array}$ & $\begin{array}{l}-0.001 \\
(-0.85)\end{array}$ & $\begin{array}{l}-0.001 \\
(-0.73)\end{array}$ \\
\hline ROA & $\begin{array}{c}-0.002 * * \\
(-2.30)\end{array}$ & $\begin{array}{c}-0.002 * * \\
(-2.29)\end{array}$ & $\begin{array}{c}-0.002 * * \\
(-2.16)\end{array}$ & $\begin{array}{c}-0.002 * * \\
(-2.26)\end{array}$ \\
\hline CASH & $\begin{array}{c}-0.007^{*} \\
(-1.81)\end{array}$ & $\begin{array}{c}-0.007^{*} \\
(-1.78)\end{array}$ & $\begin{array}{c}-0.006^{*} \\
(-1.77)\end{array}$ & $\begin{array}{c}-0.006^{*} \\
(-1.75)\end{array}$ \\
\hline$R \& D$ & $\begin{array}{l}-0.002 \\
(-0.85)\end{array}$ & $\begin{array}{l}-0.002 \\
(-0.81)\end{array}$ & $\begin{array}{l}-0.002 \\
(-0.82)\end{array}$ & $\begin{array}{l}-0.001 \\
(-0.65)\end{array}$ \\
\hline D/E RATIO & $\begin{array}{c}-0.000 * * \\
(-2.15)\end{array}$ & $\begin{array}{c}-0.000 * * \\
(-2.20)\end{array}$ & $\begin{array}{c}-0.000 * * \\
(-2.17)\end{array}$ & $\begin{array}{c}-0.000 * * \\
(-2.04)\end{array}$ \\
\hline ASSET TURNOVER & $\begin{array}{c}-0.004 * * * \\
(-3.55)\end{array}$ & $\begin{array}{c}-0.004 * * * \\
(-3.48)\end{array}$ & $\begin{array}{c}-0.004 * * * \\
(-3.53)\end{array}$ & $\begin{array}{c}-0.004 * * * \\
(-3.58)\end{array}$ \\
\hline MARKET-TO-BOOK & $\begin{array}{c}0.000 * * * \\
(3.34)\end{array}$ & $\begin{array}{c}0.000 * * * \\
(3.38)\end{array}$ & $\begin{array}{c}0.000 * * * \\
(3.53)\end{array}$ & $\begin{array}{c}0.000 * * * \\
(3.30)\end{array}$ \\
\hline CONSTANT & $\begin{array}{c}-0.021 * * * \\
(-3.46)\end{array}$ & $\begin{array}{c}-0.021 * * * \\
(-3.22)\end{array}$ & $\begin{array}{c}-0.024 * * * \\
(-3.11)\end{array}$ & $\begin{array}{c}-0.020 * * * \\
(-3.36)\end{array}$ \\
\hline ADJUSTED R SQUARED & 0.003 & 0.003 & 0.003 & 0.003 \\
\hline $\mathrm{N}$ & 43865 & 43865 & 43865 & 43865 \\
\hline
\end{tabular}




\section{Appendix}

Table A1: Logit Regression of Acquisition Likelihood on Tariff Decreases

Dependent variable is the likelihood of acquisition. TARIFF DECREASE DUMMY takes a value of 1 for industry-years that experienced a tariff decrease. Model 1 uses a $0.5 \%$ tariff decrease as the independent variable, while Models 2 and 3 use $1 \%$ and $1.5 \%$ tariff decreases respectively. SIZE is defined as the natural logarithm of total assets. NET WORKING CAPITAL is measured as the sum of inventory, accounts receivables and cash less accounts payable and debt in current liabilities. ROA is ratio of EBIT to total assets. CASH is defined as the level of cash and cash equivalents scaled by total assets while $R \& D$ is R\&D expenses scaled by total assets. D/E RATIO is measured as the ratio of long term debt to market value of equity; ASSET_TURNOVER is net sales scaled by total assets. MARKET-TO-BOOK is the ratio of market value to book value of assets. Standard errors are clustered at the firm level (t-statistics are in parentheses). All models include year and firm fixed effects. *,**, and *** denote significance at the $10 \%, 5 \%$, and $1 \%$ level, respectively.

\begin{tabular}{|c|c|c|c|}
\hline \multirow[t]{2}{*}{ Dependent Variable } & \multicolumn{3}{|c|}{ Likelihood of Acquisitions } \\
\hline & (1) & (2) & (3) \\
\hline TARIFF DECREASE DUMMY (0.5\%) & $\begin{array}{c}0.249 * * * \\
(2.60)\end{array}$ & & \\
\hline TARIFF DECREASE DUMMY (1\%) & & $\begin{array}{c}0.359 * * * \\
(3.05)\end{array}$ & \\
\hline TARIFF DECREASE DUMMY (1.5\%) & & & $\begin{array}{c}0.452 * * \\
(2.31)\end{array}$ \\
\hline SIZE & $\begin{array}{c}0.507 * * * \\
(6.35)\end{array}$ & $\begin{array}{c}0.509 * * * \\
(6.39)\end{array}$ & $\begin{array}{c}0.513 * * * \\
(6.43)\end{array}$ \\
\hline NET WORKING CAPITAL & $\begin{array}{c}0.038 \\
(1.08)\end{array}$ & $\begin{array}{l}0.037 \\
(1.04)\end{array}$ & $\begin{array}{l}0.037 \\
(1.08)\end{array}$ \\
\hline ROA & $\begin{array}{c}1.842 * * * \\
(5.14)\end{array}$ & $\begin{array}{c}1.866^{* * * *} \\
(5.21)\end{array}$ & $\begin{array}{c}1.874 * * * \\
(5.20)\end{array}$ \\
\hline CASH & $\begin{array}{c}-1.919 * * * \\
(-6.46)\end{array}$ & $\begin{array}{c}-1.916 * * * \\
(-6.47)\end{array}$ & $\begin{array}{c}-1.904 * * * \\
(-6.43)\end{array}$ \\
\hline $\mathrm{R} \& \mathrm{D}$ & $\begin{array}{c}3.273 * * * \\
(4.74)\end{array}$ & $\begin{array}{c}3.325 * * * \\
(4.80)\end{array}$ & $\begin{array}{c}3.327 * * * \\
(4.80)\end{array}$ \\
\hline D/E RATIO & $\begin{array}{c}-0.310 * * * \\
(-4.13)\end{array}$ & $\begin{array}{c}-0.312 * * * \\
(-4.14)\end{array}$ & $\begin{array}{c}-0.310 * * * \\
(-4.12)\end{array}$ \\
\hline ASSET TURNOVER & $\begin{array}{c}-1.502 * * * \\
(-8.46)\end{array}$ & $\begin{array}{c}-1.506 * * * \\
(-8.50)\end{array}$ & $\begin{array}{c}-1.508 * * * \\
(-8.45)\end{array}$ \\
\hline MARKET-TO-BOOK & $\begin{array}{c}0.059 * * * \\
(3.39)\end{array}$ & $\begin{array}{c}0.059 * * * \\
(3.42)\end{array}$ & $\begin{array}{c}0.062 * * * \\
(3.52)\end{array}$ \\
\hline Pseudo R2 & 0.084 & 0.084 & 0.084 \\
\hline $\mathrm{N}$ & 9389 & 9389 & 9389 \\
\hline
\end{tabular}




\section{References}

Acharya, V. V., Baghai, R. P., \& Subramanian, K. V. (2012). Wrongful Discharge Laws and Innovation. Working Paper.

Agrawal, A. K., \& Matsa, D. A. (2012). Labor unemployment risk and corporate financing decisions. Journal of Financial Economics.

Agrawal, A. K., \& Matsa, D. A. (2013). Labor unemployment risk and corporate financing decisions. Journal of Financial Economics, 108, 449-470.

Anderson, J. E., \& van Wincoop, E. (2004). Trade Costs. Journal of Economic Literature, 62, $691-751$.

Andrade, G., \& Stafford, E. (2004). Investigating the economic role of mergers. Journal of Corporate Finance, 10, 1-36.

Andrade, G., Mitchell, M., \& Stafford, E. (2001). New Evidence and Perspectives on Mergers. Journal of Economic Perspectives, 15, 103-120.

Asquith, P. (1983). Merger Bids, Uncertainty, and Stockholde Returns. Journal of Financial Economics, 11, 51-83.

Asquith, P., Buner, R. F., \& Mullins Jr., D. W. (1983). The Gains to Bidding Firms from Merger. Journal of Financial Economics, 11, 121-139.

Bao, C. G., \& Chen, M. X. (2013). When foreign rivals are coming to town: Firm responses to multinational investment news. Working Paper. 
Becher, D. A. (2000). The valuation effects of bank mergers. Journal of Corporate Finance, 6 , 189-214.

Becher, D. A., \& Campbell, T. L. (2005). Interstate banking deregulation and the changing nature of bank mergers. Journal of Financial Research, 28, 1-20.

Bertrand, M., Schoar, A., \& Thesmar, D. (2007). Banking Deregulation and Industry Structure: Evidence from the French Banking Reforms of 1985. Journal of Finance, 62, 597-628.

Bertrand, O., \& Zitouna, H. (2006). Trade Liberalization and Industrial Restructuring: The Role of Cross-Border Mergers and Acquisitions. Journal of Economics and Management Strategy, 15, 479-515.

Bertrand, O., Mucchielli, J.-L., \& Zitouna, H. (2007). Location Choices of Multinational Firms: The Case of Mergers and Acquisitions. Journal of Economic Integration, 22, 181-209.

Bjorvatn, K. (2004). Economic integration and the profitability of cross-border mergers and acquisitions. European Economic Review, 48, 1211-1226.

Blonigen, B. A., \& Taylor, C. T. (2000). R\&D Intensity and Acquisitions in High-Technology Industries: Evidence from the US Electronic and Electrical Equipment Industries. Journal of Industrial Economics, 48, 47-70.

Bloom, N., Sadun, R., \& Van Reene, J. (2010). Does product market competition lead firms to decentralize? American Economic Review, 100, 434-438.

Bouwman, C. H., Fuller, K., \& Nain, A. S. (2009). Market Valuation and Acquisition Quality: Empirical Evidence. Review of Financial Studies, 22, 633-679. 
Chevalier, J. A. (1995). Do LBO Supermarkets Charge More? An Empirical Analysis of the Effects of LBOs on Supermarket Pricing. Journal of Finance, 50, 1095-1112.

Claessens, S., Demirguc-Kunt, A., \& Huizinga, H. (2001). How does foreign entry affect domestic banking markets. Journal of Banking and Finance, 25, 891-911.

Devos, E., Kadapakkam, P.-R., \& Srinivasan, K. (2009). How Do Mergers Create Value? A Comparison of Taxes, Market Power, and Efficiency Improvements as Explanations for Synergies. Review of Financial Studies, 22, 1179-1211.

Dodd, P. (1980). Merger proposals, management discretion and stockholder wealth. Journal of Financial Economics, 8, 105-137.

Dunning, J. H. (1998). Location and the Multinational Enterprise: A Neglected Factor? Journal of International Business Studies, 29, 45-66.

Eckbo, B. (1985). Antimerger Policy Under the Hart-Scott-Rodino Act: A Reexamination of the Market Power Hypothesis. Journal of Law and Economics, 28, 119-149.

Eckbo, B. E. (1983). Horizontal Mergers, Collusion, and Stockholder Wealth. Journal of Financial Economics, 11, 241-273.

Fan, J. P., \& Goyal, V. K. (2006). On the Patterns and Wealth Effects of Vertical Mergers. Journal of Business, 79, 877-902.

Feenstra, R. C. (1996). U.S. Imports, 1972-1994: Data and Concordances. NBER Working Paper \# 5515. 
Feinberg, R. M. (1986). The interaction of foreign exchange and market power effects in German domestic prices. Journal of Industrial Economics, 35, 61-70.

Fernandes, A. M. (2007). Trade Policy, Trade Volumes and Plant-level Productivity in Colombian Manufacturing Industries. Journal of International Economics, 71, 52-71.

Fresard, L. (2010). Financial Strength and Product Market Behavior: The Real Effects of Corporate Cash Holdings. Journal of Finance, 65, 1097-1122.

Fresard, L., \& Valta, P. (2013). Competitive Pressure and Corporate Investment: Evidence from Trade Liberalization. Working Paper.

Grullon, G., \& Michaely, R. (2006). Corporate Payout Policy and Product Market Competition. Working Paper.

Haddad, M., \& Harrison, A. (1993). Are There Spillovers From Direct Foreign Investment. Journal of Development Economics, 42, 51-74.

Hall, B. H., Jaffe, A. B., \& Trajtenberg, M. (2001). The NBER Patent Citations Data File: Lessons, Insights and Methodological Tools. NBER Working Paper No. 8498.

Harford, J. (1999). Corporate Cash Reserves and Acquisitions. Journal of Finance, 54, 19691997.

Harford, J. (2005). What drives merger waves? Journal of Financial Economics, 77, 529-560.

Harrison, A. E. (1994). Productivity, Imperfect Competition and Trade Reform. Journal of International Economics, 36, 53-73. 
Hoberg, G., \& Phillips, G. (2010). Product market synergies and comeptition in mergers and acquisitions: A text-based analysis. Review of Financial Studies, 23, 3773-3811.

Horn, H., \& Persson, L. (2001). The equilibrium ownership of an international oligopoly. Journal of International Economics, 53, 307-333.

Jensen, M. C., \& Ruback, R. S. (1983). The market for corporate control: The scientific evidence. Journal of Financial Economics, 11, 5-50.

Kang, J.-K., \& Shivdasani, A. (1997). Corporate restructuring during performance declines in Japan. Journal of Financial Economics, 46, 29-65.

Katics, M. M., \& Petersen, B. C. (1994). The effect of rising import competition on market power: A panel data study of US manufacturing. Journal of Industrial Economics, 42, 277-286.

Kim, E. H., \& Singal, V. (1993). Mergers and market power: Evidence from the airline industry. American Economic Review, 83, 549-569.

Maksimovic, V., \& Phillips, G. (2001). The Market for Corporate Assets: Who Engages in Mergers and Asset Sales and Are There Efficiency Gains? Journal of Finance, 56, 20192065.

Maksimovic, V., Phillips, G., \& Prabhala, N. (2011). Post-merger restructuring and the boundaries of the firm. Journal of Financial Economics, 102, 317-343.

Malmendier, U., \& Tate, G. (2005). CEO overconfidence and corporate investment. Journal of Finance, 60, 2661-2700. 
Masulis, R. W., Wang, C., \& Xie, F. (2007). Corporate governance and acquirer returns. Journal of Finance, 62, 1851-1889.

Mulherin, J. H., \& Boone, A. L. (2000). Comparing acquisitions and divestitures. Journal of Corporate Finance, 6, 117-139.

Netter, J., Stegemoller, M., \& Wintoki, M. B. (2011). Implications of Data Screens on Merger and Acquisition Analysis: A Large Sample Study of Mergers and Acquisitions from 1992 to 2009. Review of Financial Studies, 24, 2316-2357.

Neyman, J., \& Scott, B. L. (1948). Consistent Estimates Based on Partially Consistent Observations. Econometrica, 16, 1-32.

Opler, T., \& Titman, S. (1993). The Determinants of Leveraged Buyout Activity: Free Cash Flow vs. Financial Distress Costs. Journal of Finance, 48, 1985-1999.

Pavcnik, N. (2002). Trade Liberalization, Exit, and Productivity Improvements: Evidence from Chilean Plants. Review of Economic Studies, 69, 245-276.

Phillips, G. M. (1995). Increased debt and industry product markets. An Empirical Analysis. Journal of Financial Economics, 37, 189-238.

Phillips, G., \& Zhdanov, A. (2013). R\&D and the Incentives from Merger and Acquisition Activity. Review of Financial Studies, 26, 34-78.

Piotroski, J. D. (2000). Value Investing: The Use of Historical Financial Statement Information to Separate Winners from Losers. Journal of Accounting Research, 38, 1-41. 
Piotroski, J. D., \& So, E. C. (2012). Identifying Expectation Error in Value/Glamor Strategies: A Fundamental Analysis Approach. Review of Financial Studies, 25, 2841-2875.

Rhodes-Kropf, M., \& Viswanathan, S. (2004). Market valuation and merger waves. Journal of Finance, 59, 2685-2718.

Romalis, J. (2005). NAFTA's and CUSFTA's impact on international trade. NBER Working Paper \# 11059.

Shleifer, A., \& Vishny, R. W. (2003). Stock market driven acquisitions. Journal of Financial Economics, 70, 295-311.

Valta, P. (2012). Competition and the cost of debt. Journal of Financial Economics, 105, 661682.

Walter, I., \& Gray, P. H. (1983). Protectionism and International Banking. Journal of Banking and Finance, 7, 597-609.

Xu, J. (2012). Profitability and capital structure: Evidence from import penetration. Journal of Financial Economics, 106, 427-446. 